\title{
Pemberian bisphenol A (BPA) oral dapat menurunkan kadar testosteron pada tikus (Rattus norvegicus) jantan galur Sprague Dawley
}

\author{
${ }^{1}$ Nuriyah, ${ }^{2}$ IGM Aman, ${ }^{3}$ Wimpie Pangkahila \\ ${ }^{1}$ Program Pascasarjana Anti-Aging Medicine \\ ${ }^{2}$ Departemen Farmakologi \\ ${ }^{3}$ Departemen Andrologi dan Seksologi \\ Fakultas Kedokteran Universitas Udayana Denpasar \\ E-mail: inoydr@gmail.com
}

\begin{abstract}
Bisphenol A (BPA) has the structural and physiological activity of estrogen and acts as an endocrine disruptor. This study was aimed to prove that oral BPA could decrease testosterone levels in male Sprague Dawley rats. This was an experimental study with a randomized pretest-posttest control group design using 14 rats (Rattus norvegicus), male, Sprague Dawley strain, 2-3 months old, as subjects. Rats were divided into two groups with 7 rats each. The control group (P0) was treated with placebo for 14 days and the treatment group (P1) was treated with oral bisphenol A (BPA) single dose of $400 \mathrm{mg} / \mathrm{kg} /$ day for 14 days (P1). At before and after 14-day treatment, blood was drawn through the canthus medial of orbital sinus to obtain the pretest and posttest data. Testosterone levels were examined by using ELISA. The results showed that before treatment (pretest), the mean testosterone level in P0 group was $8.29 \pm 4.68 \mathrm{nmol} / \mathrm{L}$, while in $\mathrm{P} 1$ group was $7.39 \pm 1.45 \mathrm{nmol} / \mathrm{L}(P>0.05)$. After treatment for 14 days, the mean testosterone level in P0 group was $7.40 \pm 1.37 \mathrm{nmol} / \mathrm{L}$, while in $\mathrm{P} 1$ group was $3.36 \pm 1.26 \mathrm{nmol} / \mathrm{L}(P<0.01)$. The statistical analysis showed that there was no difference in testosterone levels in P0 group $(P>0.05)$, meanwhile there was a very significant decrease of testosterone levels in P1 group $(P<0.01)$ after the treatment of BPA $400 \mathrm{mg} / \mathrm{kg} /$ day for 14 days. Conclusion: Oral bisphenol A (BPA) could decrease testosterone levels in male rats (Rattus norvegicus) of Sprague Dawley strain.
\end{abstract}

Keywords: bisphenol A (BPA), testosterone

\begin{abstract}
Abstrak: Bisphenol A (BPA) memiliki aktifitas hormon estrogen sehingga jika masuk ke dalam tubuh dapat menjadi endocrine disruptor. Penelitian ini bertujuan untuk membuktikan pemberian BPA oral dapat menurunkan kadar testosteron pada tikus (Rattus norvegicus) jantan galur Sprague Dawley. Jenis penelitian ialah eksperimental dengan randomized pretestpostest control group design yang menggunakan 14 ekor tikus (Rattus norvegicus) jantan, galur Sprague Dawley, berumur 2-3 bulan, yang terbagi menjadi 2 (dua) kelompok masingmasing berjumlah 7 ekor tikus. Kelompok kontrol (P0) diberikan plasebo 14 hari dan kelompok perlakuan $(\mathrm{P} 1)$ diberi BPA dosis tunggal $400 \mathrm{mg} / \mathrm{kgBB} / \mathrm{hari}$ selama 14 hari. Saat sebelum dan sesudah perlakuan selama 14 hari, darah diambil melalui chantus medial orbitalis untuk pemeriksaan pretest dan postest dan kadar testosteron diperiksa dengan metode ELISA. Hasil penelitian menunjukkan bahwa sebelum perlakuan (pretest), rerata kadar testosteron kelompok P0 8,29 $\pm 4,68 \mathrm{nmol} / \mathrm{L}$, sedangkan pada kelompok P1 7,39 $\pm 1,45 \mathrm{nmol} / \mathrm{L}(P>0,05)$. Setelah perlakuan selama 14 hari, rerata kadar testosteron kelompok P0 ialah 7,40 $\pm 1,37$ $\mathrm{nmol} / \mathrm{L}$ dan pada kelompok P1 3,36 $\pm 1,26 \mathrm{nmol} / \mathrm{L}(P<0,01)$. Analisis efek perlakuan menunjukkan tidak terjadi penurunan kadar hormon testosteron pada kelompok P0 $(P>0,05)$, sedangkan penurunan bermakna terdapat pada kelompok P1 $(P<0,01)$. Simpulan: Pemberian bisphenol A (BPA) oral dapat menurunkan kadar testosteron pada tikus (Rattus norvegicus) jantan galur Sprague Dawley.
\end{abstract}

Kata kunci: bisphenol A (BPA), testosteron 
Hormon memiliki peran yang sangat penting bahkan mutlak bagi kehidupan manusia. Beberapa faktor yang berakibat buruk bagi fungsi hormon ialah kurang berolahraga, kurang tidur, nutrisi tidak cukup atau tidak sehat, efek samping obat tertentu, dan keracunan karena lingkungan yang tidak sehat, termasuk yang masuk melalui makanan dan udara. ${ }^{1}$ Makanan dan minuman tidak bisa dilepaskan dengan bahan kimia yang berhubungan dengan pengemasan. Bisphenol A (BPA) merupakan salah satu bahan kimia sintetik yang sangat banyak diproduksi dewasa ini. Bahan ini merupakan monomer dalam sintesis epoksi resin. Epoksi resin digunakan sebagai bahan pelapis dinding dalam kemasan makanan dan minuman. ${ }^{2}$

Dalam bentuk aktif, senyawa BPA memiliki aktifitas hormon estrogen sehingga jika masuk ke dalam tubuh dapat memimik (meniru) hormon estrogen. Oleh karena itu para peneliti memberikan perhatian yang cukup besar terhadap BPA dan kemungkinan efeknya terhadap manusia. Selain itu, BPA juga merupakan salah satu senyawa endocrine disruptors yang dapat mengganggu biosintesis, sekresi, kerja, atau metabolisme alami suatu hormon. ${ }^{3}$

Bisphenol A yang masuk kedalam tubuh melalui pangan dapat diserap dalam saluran cerna lalu dimetabolisme di dalam hati membentuk senyawa yang inaktif, yaitu konjugat BPA-glucoronic acid yang tidak memiliki aktifitas hormonal dan tidak berbahaya. Senyawa ini bersifat larut dalam air sehingga dapat dikeluarkan melalui urin. Selain itu terdapat pula senyawa inaktif lain yang dihasilkan dalam jumlah yang lebih sedikit, yaitu BPA sulfat. Baik BPA-glucoronic acid mapun BPA sulfat keduanya dapat diukur kadarnya dalam tubuh, namun hanya BPA bentuk bebas (BPA bentuk aktif saja) yang berpotensi menimbulkan efek merugikan bagi kesehatan. $^{3}$

Beberapa penelitian lain menunjukkan bahwa BPA, baik dalam bentuk aktif maupun inaktif, mampu menembus plasenta. BPA bebas yang telah menembus plasenta dan mencapai fetus, kebanyakan tetap berada dalam bentuk aktifnya, sedangkan bila senyawa yang menembus plasenta ialah bentuk inaktifnya maka senyawa tersebut dapat diubah menjadi BPA bentuk aktif. Pada fetus, perubahan BPA inaktif menjadi aktif ini dimungkinkan karena organ hati dan jantungnya dapat menghasilkan enzim yang mampu mengubah senyawa konjugat BPAglucoronic acid menjadi BPA-estrogenic yang toksik. ${ }^{3}$

Studi akhir-akhir ini menunjukkan bahwa paparan BPA dalam jangka waktu lama berhubungan dengan peningkatan penyakit yang berhubungan dengan penuaan. Tan et al. ${ }^{4}$ melaporkan dalam penelitiannya bahwa paparan BPA meningkatkan aging process pada nematode Caenorhabbditis elegans, terjadi pengurangan panjang tubuh, kesuburan, dan jumlah populasi, serta banyaknya telur yang cacat.

Hasil penelitian Nakamura et al. ${ }^{5}$ menyatakan bahwa BPA menyebabkan reproductive toxicities tetapi mekanismenya masih belum jelas. Penelitian tersebut membandingkan antara 17 $\beta$-estradiol (E2) dan BPA; keduanya menurunkan kadar testosteron dalam plasma dan testis, dan juga luteinizing hormone (LH) plasma. Pemberian BPA secara subkutan dengan dosis $200 \mathrm{mg} / \mathrm{kg}$ BPA dan $100 \mu \mathrm{g} / \mathrm{kg}$ E2 secara bermakna menurunkan jumlah sel Leydig pada testis namun pada penelitian yang dilakukan oleh Sanchez et al. ${ }^{6}$ didapatkan bahwa pemberian BPA dosis rendah tidak menurunkan kadar testosteron pada tikus Wistar jantan.

Hormon testosteron berperan penting dalam proses penuaan. Penelitian ini bertujuan untuk untuk membuktikan pemberian BPA oral dapat menurunkan kadar testosteron pada tikus (Rattus norvegicus) jantan galur Sprague Dawley.

\section{METODE PENELITIAN}

Jenis penelitian ini ialah eksperimental dengan menggunakan randomized pretestpostest control group design. ${ }^{7}$ Subjek penelitian ialah 14 ekor tikus putih jantan 
galur Sprague Dawley, umur 2-3 bulan, berat badan $\pm 150-160$ gr, dan sehat; yang dibagi menjadi 2 kelompok dengan masingmasing kelompok berjumlah 7 ekor tikus. Satu kelompok sebagai kelompok kontrol (P0) yang diberikan plasebo selama 14 hari dan kelompok lainnya ialah kelompok perlakuan (P1) yang diberi BPA dosis tunggal $400 \mathrm{mg} / \mathrm{kgBB} / \mathrm{hari}$ untuk setiap tikus selama 14 hari. Sebelum penelitian dimulai, tikus diadaptasi selama satu minggu di tempat penelitian untuk penyesuaian dengan lingkungan. Pada hari ke-8, diambil sampel darah melalui canthus medial orbitalis untuk pemeriksaan kadar testosteron pretest. Setelah 14 hari perlakuan sesuai dengan kelompoknya, diambil sampel darah melalui canthus medial orbitalis untuk pemeriksaan kadar testosteron posttest. Kadar hormon testosteron diperiksa dengan metode ELISA yaitu Sandwich ELISA ${ }^{8}$ dan dibaca dengan spektrofotometer 450nm.

\section{HASIL DAN BAHASAN}

Hasil penelitian ini menunjukkan rerata kadar testosteron kelompok kontrol (P0) sebelum diberikan perlakuan (pre test) ialah $8,29 \pm 4,68 \mathrm{nmol} / \mathrm{L}$, sedangkan pada kelompok perlakuan $(\mathrm{P} 1)$ yang diberi BPA dengan dosis tunggal $400 \mathrm{mg} / \mathrm{kgBB} / \mathrm{hari}$ tikus $7,39 \pm 1,45 \mathrm{nmol} / \mathrm{L}(P>0,05)$. Setelah perlakuan selama 14 hari (post test), rerata kadar testosteron kelompok kontrol (P0)

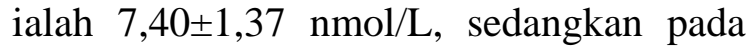
kelompok perlakuan (P1) 3,36 $\pm 1,26$ nmol/L $(P<0,01)$ (Tabel 1).

Untuk mengetahui efek pemberian masing-masing jenis perlakuan terhadap variabel penelitian, maka data dianalisis lebih lanjut menggunakan t-paired test. Hasil analisis efek perlakuan menunjukkan tidak terjadi penurunan kadar hormon testosteron pada kelompok kontrol (P0) yang diberikan plasebo berupa aquadest $(P$ $>0,05)$, namun pada kelompok perlakuan (P1) dapat diamati terjadinya penurunan kadar hormon testosteron yang sangat bermakna $(P<0,01)$ setelah diberikan perlakuan berupa BPA dosis 400mg/kgBB/hari selama 14 hari (Tabel 2).

Tabel 1. Perbandingan rerata kadar testosteron antar kelompok

\begin{tabular}{|c|c|c|c|c|c|}
\hline Pemeriksaan & Kelompok & $\mathbf{n}$ & $\begin{array}{c}\text { Rerata testosteron } \\
(\mathrm{nmol} / \mathrm{L})\end{array}$ & $t$ & $P$ \\
\hline \multirow[t]{2}{*}{ Pretest } & Kontrol (P0) & 7 & $8,29 \pm 4,68^{\mathrm{a}}$ & \multirow{2}{*}{0,492} & \multirow{2}{*}{0,632} \\
\hline & Perlakuan (P1) & 7 & $7,39 \pm 1,45^{\mathrm{a}}$ & & \\
\hline \multirow[t]{2}{*}{ Posttest } & Kontrol (P0) & 7 & $7,40 \pm 1,37^{\mathrm{a}}$ & \multirow[t]{2}{*}{5,747} & \multirow{2}{*}{0,000} \\
\hline & Perlakuan (P1) & 7 & $3,36 \pm 1,26^{\mathrm{b}}$ & & \\
\hline
\end{tabular}

*Notasi (a,b) yang berbeda menunjukkan berbeda bermakna $(P<0,05)$

Tabel 2. Hasil analisis efek perlakuan pretest-posttest data kadar testosteron

\begin{tabular}{lccccc}
\hline \multirow{2}{*}{ Kelompok subjek } & \multicolumn{2}{c}{$\begin{array}{c}\text { Kadar testosteron } \\
\text { (nmol/L) }\end{array}$} & $\begin{array}{c}\text { Rerata } \\
\text { perbedaan }\end{array}$ & t & $\boldsymbol{P}$ \\
\cline { 2 - 3 } & Sebelum & Sesudah & & & \\
\hline Kontrol (P0) & $8,29 \pm 4,68$ & $7,40 \pm 1,37$ & 0,89 & 0,427 & 0,684 \\
Perlakuan (P1) & $7,39 \pm 1,45$ & $3,36 \pm 1,26$ & 4,03 & 8,514 & 0,000 \\
\hline
\end{tabular}

Bisphenol A (BPA) ialah suatu bahan kimia sintetik berupa monomer penyusun plastik yang banyak digunakan dalam produksi plastik polikarbonat (PC) dan epoksi resin. Polikarbonat ialah polimer termoplastik, mudah dibentuk dengan menggunakan panas, dan merupakan senyawa hasil pertukaran ester antara BPA dan difenilkarbonat. Untuk membedakan jenis plastik, PC mempunyai kode nomor 
“7”. Plastik yang berbahan PC merupakan plastik yang ringan, kuat, jernih, dan tahan terhadap panas. Hal penting yang harus diperhatikan dalam penggunaan plastik PC ialah adanya material BPA di dalamnya yang dapat bermigrasi kedalam makanan/ minuman jika terkena paparan panas (suhu $\left.>70^{\circ} \mathrm{C}\right) .{ }^{9,10}$ Polikarbonat dipakai secara luas dalam berbagai macam produk termasuk botol bayi dan botol minuman, alat-alat kedokteran, CD, dan elektronik rumah tangga. ${ }^{11}$

Bisphenol A juga digunakan sebagai senyawa antara dalam produksi epoksi resin. Epoksi resin terikat silang merupakan bahan inert dan digunakan sebagai lapisan pelindung pada kaleng logam untuk menjaga kualitas makanan dan minuman dalam kaleng. Lapisan tersebut berfungsi untuk melindungi makanan atau minuman dari kontak langsung dengan logam. Beberapa keunggulan lain dari epoksi resin ialah kekuatan fisik dan resistennya terhadap bahan kimia, sehingga senyawa ini cukup luas digunakan sebagai lapisan pelindung. 9,10

Umumnya orang terpapar dengan BPA melalui wadah makanan dan minuman. Bisphenol A dapat bermigrasi ke makanan dari lapisan epoksi resin dan dari produk plastik PC. Pemanasan pada plastik, seperti microwave, meningkatkan migrasi $\mathrm{BPA}^{10}$ Bisphenol A merupakan endocrine disruptor yang memiliki aktifitas androgenik tetapi dalam bentuk aktifnya, senyawa BPA memiliki aktifitas estrogen sehingga jika masuk kedalam tubuh dapat memimik (meniru) hormon estrogen. ${ }^{12}$

Hasil penelitian menunjukkan bahwa rerata kadar testosteron pada kelompok kontrol (PO) sesudah diberikan plasebo aquadest $2 \mathrm{ml}$ selama 14 hari (posttest) ialah $7,40 \pm 1,37 \mathrm{nmol} / \mathrm{L}$, sedangkan kelompok perlakuan (P1) yang diberi BPA dosis $400 \mathrm{mg} / \mathrm{kgBB} / \mathrm{hari}$ ialah $3,36 \pm 1,26 \mathrm{nmol} / \mathrm{L}$ $(P<0,01)$. Selain itu, hasil analisis efek perlakuan menunjukkan bahwa pada kelompok perlakuan (P1) terjadi penurunan kadar hormon testosteron yang sangat bermakna dari 7,39 $\pm 1,45 \mathrm{nmol} / \mathrm{L}$ menjadi 3,36 $\pm 1,26$ setelah 14 hari diberikan perlakuan berupa BPA dosis $400 \mathrm{mg} / \mathrm{kgBB} /$ hari $(P<0,01)$ (Gambar 1$)$. Hasil penelitian ini terkait dengan aktifitas estrogenik yang dimiliki oleh BPA.

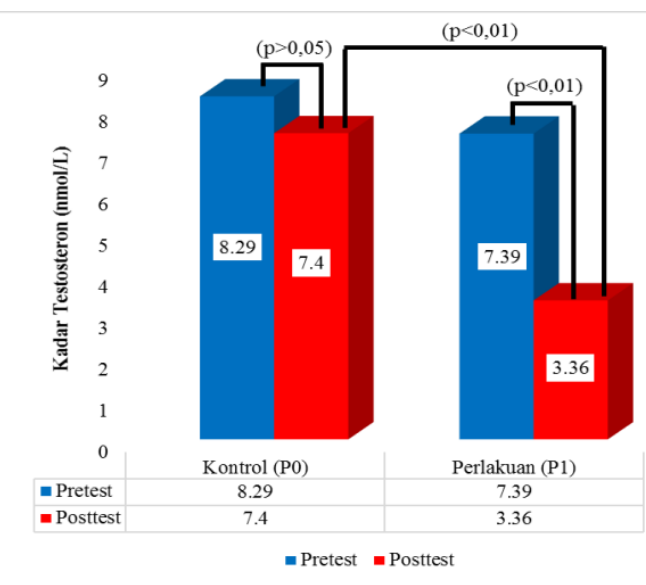

Gambar 1. Perubahan kadar testosteron sebelum dan sesudah perlakuan antar kelompok perlakuan

Beberapa penelitian terdahulu menunjukkan hasil yang serupa dengan hasil penelitian ini. Penelitian yang dilakukan oleh Nakamura et al. menunjukkan bahwa pemberian BPA dan E2 pada tikus wistar jantan prepubertas dengan dosis $100 \mathrm{mg} / \mathrm{kgBB} / \mathrm{hari}$ dan $200 \mathrm{mg} / \mathrm{kgBB} /$ hari selama 6 minggu secara subkutan dapat menurunkan kadar hormon testosteron plasma dan testis, LH plasma, dan juga menyebabkan morfologi abnomal seperti penurunan jumlah sel Leydig. Penelitian lainnya yang dilakukan oleh Zhijun et al. ${ }^{12}$ menunjukkan bahwa pemberian BPA pada mencit jantan dengan dosis $100 \mathrm{mg} / \mathrm{kgBB} /$ hari selama 21 hari secara intraperitoneal dapat menurunkan kadar hormon testosteron secara bermakna.

Dosis BPA yang digunakan dalam penelitian ini melalui pemberian oral. Jika dibandingkan dengan penelitian lain dengan BPA yang diberikan secara subkutan dan intraperitonial, maka dosis oral digunakan lebih besar. Hal ini berhubungan dengan farmakokinetik dari BPA yang menunjukkan absorbsi intestinal yang cepat, dan sangat cepat terjadi konjugasi BPA dengan UDP-glucoronic acid, membentuk BPA glucoronide 
(BPAG). Eliminasi BPAG pada manusia dan kera terjadi secara cepat $\left(\mathrm{t}_{1 / 2}=3-4\right.$ jam $)$ dan terutama melalui urin. Eliminasi dari BPAG pada tikus dan mencit lebih kompleks, dengan terjadinya siklus utama ke empedu dan masuk ke usus, dimana bacterial glucoronidase mengubah BPAG menjadi bentuk free-BPA kembali, yang dapat diserap kembali. Penyerapan kembali BPA melalui usus tikus sekitar $50 \% .^{13}$

Pottenger et al. $^{14}$ melakukan studi farmakokinetik dan metabolisme dari BPA melalui pemberian oral, intraperitoneal (IP), dan subkutan (SC) dengan dosis $10 \mathrm{mg} / \mathrm{kgBB} / \mathrm{hari}$ dan $100 \mathrm{mg} / \mathrm{kgBB} /$ hari pada tikus jantan dan betina selama 7 hari. Hasil studi ini menunjukkan bahwa BPA terutama dieliminasi melalui feses (52$85 \%$ ), dengan jumlah terkecil dalam urin (13-34\%). Pada residu jaringan setelah 7 hari ditemukan 1-2\% dari dosis BPA. BPA glucoronide merupakan konjugasi yang besar di urin (60-87\%), diikuti oleh free BPA (3-12\%) dan BPA sulfat (2-7\%). Diperkirakan bahwa metabolisme BPA di dalam usus dan oleh hepatic UDP glucoronyl transferase (UGT) menjadi bentuk BPA glucoronide, metabolit utama di dalam plasma (68-100\%) pada pemberian oral, sedangkan pada IP yaitu 27-69\% dan subkutan 17-49\%.

BPA merupakan endocrine disruptor yang bisa meniru estrogen dan dapat mengakibatkan efek negatif BPA berupa peningkatan risiko obesitas, brain diseases, gangguan sistem hormon dan reproduksi, asma, dan juga penyakit jantung serta kanker. ${ }^{15}$

Terdapat berbagai mekanisme bagaimana BPA sebagai endocrine disruptor dapat menurunkan kadar hormon testosteron namun dalam penelitian ini kemungkinan mekanisme kerja BPA yang paling utama ialah menganggu biosintesis testosteron dan meningkatkan level reseptor estrogen. ${ }^{16}$ Bisphenol A mempunyai struktur molekul yang mempunyai kemampuan untuk berikatan dengan 2 estrogen reseptor (ER $\alpha$ dan ER $\beta)$ meskipun BPA mempunyai kemampuan 1000-2000 kali lebih lemah dibandingkan
E2 yang merupakan estrogen aktif. ${ }^{17}$

Bisphenol A dapat mengganggu aksi estrogen endogen dengan mengganggu aktifitas reseptor nuklear estrogen karena BPA dapat meniru aksi dari $17 \beta$ estradiol, juga dapat memodifikasi aktifitas ekspresi enzym cytochrome P450 dan enzim lainnya di dalam biosintesis testosteron seperti 17ßHSD. ${ }^{16}$ Dapat disimpulkan bahwa efek endocrine disruptor bekerja melalui aktivasi atau inhibisi dari reseptor androgen dan estrogen. ${ }^{18}$

\section{SIMPULAN}

Berdasarkan hasil penelitian ini dapat di simpulkan bahwa pemberian BPA oral dapat menurunkan kadar hormon testosteron tikus (Rattus norvegicus) jantan galur Sprague Dawley secara bermakna.

\section{DAFTAR PUSTAKA}

1. Pangkahila W. Anti-Aging Tetap Muda dan Sehat. Jakarta: Kompas Media Nusantara, 2011; p. 7-94.

2. Peretz J, Vrooman L, Ricke AW, Hunt PA, Ehrlich S, Hauser R, et al. Bisphenol A and reproductive health: Updated of experimental and human evidence, 2007-2013. Environ Health Perspect. 2014;122:775-86.

3. Sipahutar H, Gaol A, Silalahi A. Akselearsi pencapaian pubertas mencit setelah pendedahan xenoestrogen Bisphenol A (BPA) selama dua generasi berturutturut. J Sains MIPA. 2007;89(2):95105.

4. Tan L, Wang S, Wang Y, He M, Liu D. Bisphenol A exposure accelerated the aging process in the nematode Caenorhabditis elegans. Toxicol Lett. 2015;235:75-83.

5. Nakamura D, Yanagiba $Y$, Duan $Z$, Ito $Y$, Okamura A, Asaeda N, et al. 2010. Bisphenol A may cause testosterone reduction by adversely affecting both testis and pituitary system similar to estradiol. Toxicol Lett. 2010;194:16-25.

6. Sanchez P, Castro B, Torres JM, Olmo A, Moral RG, Ortega E. 2013. Bisphenol A modifies the regulation exerted by testosterone on $5 \alpha$-reductase isozymes in ventral prostate of adult rats. BioMed Research International. 2013;2013. 
Article ID 629235.

7. Pocock SJ. Clinical Trials. A Practical Approach. Chichester: John Wiley and sons, 2008; p. 68-129.

8. Rantam FA. Metode Imunologi. Surabaya : Airlangga University Press, 2003; p. 83.

9. Direktorat Pengawasan Produk dan Bahan Berbahaya. Badan POM RI. 2014. Mengenal bisphenol A (BPA) pada kemasan pangan. InfoPOM. 2014;15(2): 6-8.

10. Bahaya paparan bisphenol A. 2015. [cited 2016 Sept 1]. Avalaible from: http://ik.pom.go.id/v2015/artikel/ Bahaya-paparan-Bisphenol-A-pdf.

11. Carlisle J, Chan D, Henkel S, Painter P, Wu KL. Toxicological Profile for bisphenol A. 2009. [cited 2016 Aug 26]. Avalaible from: http: //www.opc.ca.gov/webmaster/ftp/proje ct_pages/MarineDebris_OEHHA_Tox Profiles/BisphenolAFinal.Pdf.

12. Zhijun Z, Suyun J, Tingting $X$, Shizong $H$. Effects of bisphenol A on testosterone levels and sexual behaviours of male mice. ASM. 2016;6:41-9.

13. Rooth WL, Komolprasert V. Compact summary of bisphenol A (BPA) poharmacokinetics. Public Health
Service Food and Drug Administration, 2017.

14. Pottenger LH, Domoradzki JY, Markham DA, Hansen SC, Cagen SZ, Waechter JM. The relative bioavailability and metabolism of bisphenol $\mathrm{A}$ in rats is dependent upon the route of administration. Toxicol Sci. 2000;54:3-18.

15. Rezg R, El-Fazaa S, Gharbi N, Mornagui B. Bisphenol A and human chronic diseases: current evidence. Possible mechanisms and future perspectives. Environ Int. 2014;64:83-90.

16. Alharthy AS. The effect of endocrine disrupting chemical bisphenol A on testosterone biosynthesis [Thesis]. San Antonio: The University of Texas Health Science Center; 2014.

17. Bolli A, Galluzzo P, Ascenzi P, Del Pozzo G, Manco I, Vietri MT, et al. Laccase treatment impairs bisphenol A- induced cancer cell proliferation affecting estrogen receptor alpha-dependent rapid signals. IUBMB Life. 2008;60(12):843-52.

18. Knez J. Endocrine-disrupting chemicals and male reproductive health. Reprod Biomed Online. 2013;26(5):440-8. 